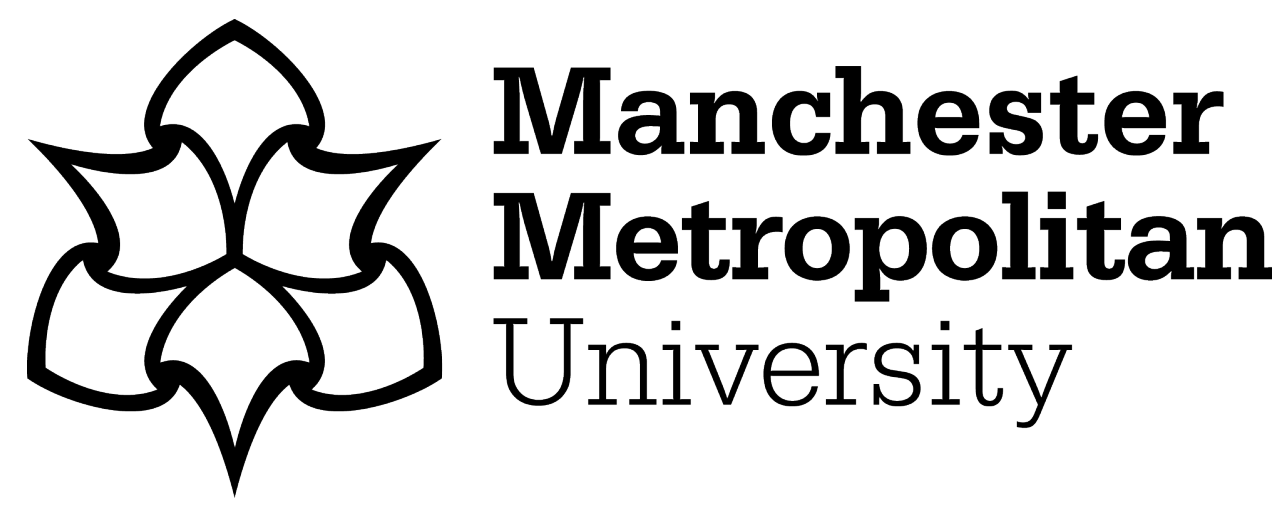

Kauppi, K and Hannibal, CL (2017) Institutional Pressures and Sustainability Challenges in Supply Chains. Supply Chain Management: An International Journal, 22 (5). pp. 458-472. ISSN 1359-8546

Downloaded from: https://e-space.mmu.ac.uk/620615/

Publisher: Emerald

DOI: https://doi.org/10.1108/SCM-01-2017-0004

Please cite the published version 


\title{
Institutional pressures and sustainability assessment in supply chains
}

\begin{abstract}
Purpose: Firms are increasingly held accountable for the welfare of workers across entire supply chains and so it is surprising that standard forms of governance for socially sustainable supply chain management have not yet emerged. Assessment initiatives have begun to develop as a proxy measure of social sustainable supply chain management. This research examines how social sustainability assessment initiatives instigate and use institutional pressures to drive third party accreditation as the legitimate means of demonstrating social sustainability in a global supply chain.
\end{abstract}

Design/methodology/approach: Ten assessment initiatives focused on assuring social sustainability across supply chains are examined. Data is collected through interviews with senior managers and publicly available secondary material.

Findings: The findings show how the social sustainability assessment initiatives act by instigating institutional pressures indirectly rather than directly. Coercive pressures are the most prevalent and are exerted through consumers and compliance requirements. The notion of pressures operating as a chain is proposed, and the recognition that actors within and outside of a supply chain are crucial to the institutionalization of social sustainability is discussed.

Originality/value: Studies on sustainable supply chain management often focus on how companies sense and act upon institutional pressures. To add to the extant body of knowledge this study focuses on the sources of the pressures and demonstrates how assessment initiatives use coercive, normative and mimetic pressures to drive the adoption of social sustainability assessment in supply chains. 


\section{Introduction}

Research on social sustainability is gaining momentum to keep pace with firms' heightened interest in the topic as previously its application to the supply chain domain has been limited, particularly when compared to research on environmental sustainability (Marshall et al., 2015a). The supply chain function is critical in terms of both its efforts to deliver on social sustainability goals as well as mitigating the exposure to risk for buyers. For example, the use of child labor and poor labor practices by a supplier can significantly damage company, and supply chain, reputation and performance (Grosvold et al., 2014; Sancha et al., 2015). Research focusing on environmental sustainability in supply chains often adopts an institutional theory or stakeholder perspective on why firms adopt such green practices (e.g. González et al. 2008; Wu et al., 2012). Institutional theory, with its focus on conformance (DiMaggio and Powell, 1983), also provides a fitting lens for investigating social sustainability in supply chains and we use it to frame our research on the adoption of social sustainability assessment in global supply chains.

There are several streams of institutional theory, and our focus is on the variant whereby institutional elements are viewed as a class of elements that explain the existence and persistence of certain organizational forms (Scott, 1987), dating to the works of Meyer and Rowan (1977). We build on DiMaggio and Powell's (1983) work on institutional pressures causing isomorphism in organizational forms. Extensive research emphasizes the role of institutional mechanisms in diffusing organizational practices; the most prevalent of which focuses on the three institutional pressures - normative, coercive and mimetic. Institutional theory oriented research within supply chain management $(\mathrm{SCM})$ in particular is often more focused on the impacts of the adoption of practices, rather than on how certain practices originally come to be seen as legitimate or on the strategies of social movements (Bruton et al., 2010; Burchell and Cook, 
2013; Kauppi, 2013). Thus researchers are urged to study the standard setting organizations and their role in changing sustainability practices along product supply chains (Ingenbleek and Reinders, 2013). Studying diffusions of practices and the ensuing isomorphism is contingent upon identifying the agents of institutional diffusion as well as the channels used (Guler et al., 2002).

In this study our aim is to investigate how institutional pressures are exerted on supply chain actors by voluntarily adopted third party assessment initiatives ${ }^{1}$ to reinforce social sustainability as the legitimate way of doing business. This approach has been defined as process-based as it involves the monitoring of the trading practices of supply chains (Marshall et al., (in press)). While recognizing how voluntary assessment initiatives are only one of the likely sources of social sustainability pressure for companies, we chose to investigate these initiatives as given their role in socially sustainable supply chains, instigating such pressures would appear to be their raison d'etre. As not all of these organizations certify or formally accredit supply chain actors, but rather expect codes of conduct or guidelines to be adhered to, we have used the collective term of social sustainability assessment initiative to capture the essence of the organization. These assessment initiatives expect all firms to use clearly defined and transparent socially sustainable trading practices in their business operations i.e. to exhibit isomorphism in their supply chains when it comes to social sustainability. Their goal is for social sustainability to

\footnotetext{
${ }^{1}$ Throughout the study we focus on social sustainability initiatives based on voluntary standards and third party verification processes rather than those that are mandatory or private and therefore either a legal requirement or internally developed and monitored by firms (Giovannucci and Ponte, 2005). Voluntary standards are perceived as having greater legitimacy than private standards as they are independent from corporations (Gereffi, et al., 2005) and focus on external authentication (Giovannucci and Ponte, 2005).
} 
be seen as the only legitimate way to conduct trading relations, particularly with producers located in the global South (Reinecke et al., 2012).

Our chosen focus is to develop current understanding of the institutional pressures exerted by third parties on supply chain actors to voluntarily adopt social sustainability assessment. To date, research on supply chain sustainability has focused more significantly on environmental, rather than social, aspects (Morali and Searcy, 2013; Moxham and Kauppi, 2014; Sancha et al., 2015). In particular, the use of institutional theory in social sustainability context has been limited in supply chain management research (Zorzini et al., 2015). As noted, research in this area has studied the impact of adopting certain practices and hence there is a paucity of research examining how certain practices originate. Thus by studying how social sustainability pressures are exerted on supply chain actors we offer an important complementary viewpoint to the prevalent stream of research focusing on the "outcome" of this process, i.e. the adoption of practices at firm level due to institutional pressures. By investigating the origins of how pressures are applied to firms as part of institutionalizing a new supply chain governance approach we provide a comprehensive analysis of how supply chain practices become institutionalized.

Utilizing social, rather than environmental, sustainability as the context of our investigation of institutional pressures is suitable given the increasing amount of studies pointing to the performance benefits of environmental practices (e.g. Rao and Holt, 2005; Vachon and Klassen, 2008; Green et al. 2012). These findings suggest that in the future institutional pressures may have a more limited role in the adoption of environmental practices as firms will adopt them for 
predominantly economic gains. For social sustainability similar performance benefits are not (at least yet) demonstrated widely, and so this context is likely to offer a richer study setting to examine institutional pressures. Further, as Kauppi (2013) notes, the operationalization of institutional pressures is not yet well developed. Thus our qualitative case study approach to the origins of social sustainability pressures is both suited given the maturity of institutional theory applications in socially sustainable supply chain management, as well as important in helping future research better understand the forms of institutional pressures organizations face.

Our findings also have implications for practice. We are able to provide managerial guidance to firms striving for legitimacy in their sustainable supply chain practices as well as to assessment initiatives in their quest to become mainstream and influence organizational practices. Identifying the approaches by which firms are pressured to adopt certain supply chain practices to enhance legitimacy can assist firms in making more informed choices regarding their engagement with third party assessment.

In the following, we first present the literature review of institutional theory with a focus on normative, coercive and mimetic institutional pressures (DiMaggio and Powell, 1983). We review this literature with respect to socially sustainable supply chain management and pose a research question to frame our study. We then explain our methodology, as well as the results of the data analysis. We discuss our findings and offer conclusions. Finally, we acknowledge the limitations of the study and provide suggestions for further work in this area. 


\section{Literature review: institutional isomorphism through pressures to conform}

Institutional theorists see organizational action as a result of exogenous sources that modify organizational decision-making (Heugens and Lander, 2009). The theory has been used to explain the persistence of certain organizational structures and ideals (Weerakkody et al., 2009). The adoption of legitimated elements increases an organization's survival probability as legitimacy is needed to gain support from one's constituents (Lamin and Zaheer, 2012; Maclean and Benham, 2010). Conformance with what is legitimate simultaneously leads to an organizations' isomorphism with its environment (Heugens and Lander, 2009; Zucker, 1987). Institutional pressures originate from e.g. regulatory structures, cultural practices, influence of dominant organizations, and explain the cohesion of organizations, fields and industries (DiMaggio and Powell, 1983). Firms seek the approval of - and thus follow the guidelines from these actors as they provide important support for firm legitimacy (Heugens and Lander, 2009). The institutional pressures that drive isomorphism and guide what is legitimate, as defined by DiMaggio and Powell (1983), take three forms: normative, coercive and mimetic. We present each of these in the following sections, discuss them in relation to the context of our study and develop a research question designed to extend the current line of enquiry.

\section{Normative pressure}

Normative pressures concern organizational domains establishing joint control over how the field and/or profession operates (Heugens and Lander, 2009). Normative isomorphism relates to the logic of appropriateness (Guler et al., 2002); trade associations, professional associations and accreditation bodies are normative institutions as they create codes of conduct that are perceived as appropriate (Grewal and Dharwadkar, 2002). Industry associations work to promote an 
industry's collective reputation and professional networks can cause similar standards and models to spread across firms (Castka and Balzarova, 2008; Grewal and Dharwadkar, 2002). DiMaggio and Powell (1983) propose that greater involvement in associations will lead a firm to resemble those in its field. Suppliers are prone to adopt environmental practices conforming to those advocated by the industry coalitions to which they belong (Tate et al., 2014). Presumably, an association or a network of firms that is part of an assessment initiative would foster this resemblance towards its own codes of conduct. It therefore follows that normative pressures are a natural fit for social sustainability assessment initiatives to compel firms to adopt particular standards.

Normative pressure can also be exerted through formal education (DiMaggio and Powell, 1983). An employee's training is expected to impact the practices they adopt (Guler et al., 2002). In reference to social sustainability, fair trade organizations could attempt to spread the norms of the ideology by taking an active role in collaborating with universities and colleges offering SCM in their curricula (Moxham and Kauppi, 2014). For SCM practices it is anticipated that those assessing social sustainability will exert normative pressure on firms to adopt socially sustainable practices in their supply chains. They can potentially introduce social sustainability as a norm by integrating closely with the industry and the education sector (Moxham and Kauppi, 2014). Whilst we can speculate the forms that normative pressure may take in the social sustainability and SCM context, surprisingly we found limited research that explicitly examined this theme.

Coercive pressure 
Coercive pressure arises from other organizations to which a firm is dependent (DiMaggio and Powell, 1983). This usually means critical sources of organizational resources or governments with legislative power (Heugens and Lander, 2009). For example firms have been shown to adopt green practices to avoid sanctions and as a reaction to external constraints (Bansal and Roth, 2000). Multinational corporations can exert coercive pressures to implement international quality standards on those that rely on them for resources (Perez-Aleman, 2011). Coercive pressure is not only exerted by legal sources and governments or powerful firms, it can also originate from social movements (Hayagreeva and Sivakumar, 1999). A key contributor to the adoption of corporate social responsibility has been pressure from activists, non-governmental organizations (NGOs) and consumers (Castka and Balzarova, 2008). Currently, international labor laws are at a minimum level due to limited governance and activists are demanding increases (Park-Poaps and Rees, 2010). Assessment initiatives could attempt to lobby for more governmental mandates to certify supply chains.

Using codes of conduct as dictated by the most powerful member of a multinational supply chain is also common (Castka and Balzarova, 2008). Powerful players, for example supermarkets, exert coercive pressure on other actors in food supply chains to comply with environmental policies (Glover et al., 2014). Retailers can act as change agents for sustainability labeling schemes, and the adoption of environmental certifications diffuses upstream in supply chains through the demands imposed on suppliers (González et al., 2008; Hartlieb and Jones, 2009). The distribution of power in supply chains is often mentioned as a mechanism for the implementation of standards (Adebanjo et al., 2013; Yawar and Seuring, 2017), yet there is limited research examining how these mechanics work. Potentially the originating source could 
be assessment initiatives targeting powerful players and retailers for early adoption. Consumers are also a powerful force in improving labor relations in global chains given their financial influence on firms (Park-Poaps and Rees, 2010), and are thus an indirect means to exert coercive pressures on firms. Sustainability standards adoption may also be the 'responsible' response from firms under close examination by social and environmental 'watchdogs' (Wijen, 2014). Based on these previous findings, we are interested in finding examples of how social sustainability assessment initiatives apply coercive pressures and through which channels.

\section{Mimetic pressure}

Mimetic isomorphism is a response to uncertainty; when there is no clear course of action it can be safer to imitate others' behaviors (DiMaggio and Powell, 1983). Targets for mimicking are typically selected by organizational traits, outcomes or frequencies of occurrence (Haunschild and Miner, 1999). Mimicking can occur through direct contacts or by choosing organizations with structural similarity despite no direct ties (Hayagreeva and Sivakumar, 1999; PerezAleman, 2011). Within environmental management research it has been discovered that industry peers have a significant impact on a firm's environmental strategy (Bansal and Roth, 2000; ParkPoaps and Rees, 2010). Firms in the same marketing channel can copy the structures and processes of other channels against which they benchmark (Grewal and Dharwadkar, 2002). Providing communication channels with prior adopters of a practice where information and experiences can be shared is likely to induce the adoption of a new practice (Okhmatovskiy and David, 2012). The literature suggests that mimetic pressure is exerted on supply chains by NGOs working with large, successful firms (e.g. retailers or consumer goods brands) to promote the adoption of assessment against standards and also by creating platforms for firms to meet and 
share good practice (Park-Poaps and Rees, 2010). To date there are limited studies that examine this phenomenon in the context of socially sustainable SCM.

\section{Development of Research Question}

For supply chains, the consequences of failure in social sustainability can be disastrous and impact on human life and the welfare of workers (e.g. Rana Plaza). Failure can result in consumer suspicion, which can manifest as reduced consumption or boycott (Grappi et al., 2013; Klein et al., 2004). High profile cases may harm a firm's reputation and hence financial reparations may be incurred. For example, in 2003 Nike donated $\$ 1.5$ million to the Fair Labor Association following court proceedings related to protecting the human rights of its workforce (Russell et al., 2016). Yet there has been limited examination of how institutional pressures are exerted on supply chain actors to propagate the new and emerging form of social sustainability governance: social sustainability assessment.

Institutional theory provides a suitable frame to investigate interactions between stakeholders and companies (Morali and Searcy 2013). Under each of the three pressures, several manifestations are discussed and empirically examined in previous sustainable SCM research; however this is predominantly from the viewpoint of the pressure recipients and focused on environmental sustainability (see e.g. Zhu and Sarkis, 2007; Wu et al., 2012; Zhu et al., 2013; Glover et al., 2014). We know how companies react to institutional pressures, i.e. under which contexts they lead to the adoption of environmental practices, but the practices themselves are less clear. They are often framed as a given in (predominantly survey) studies, but their development and emergence is not examined. Yet the institutionalization of organizational 
practices originates somewhere, and our aim is to study assessment initiatives' role in this. We thus pose the following question:

RQ: How do social sustainability assessment initiatives exert normative, coercive and mimetic pressures on firms to adopt socially sustainable practices in their supply chains?

\section{Research Methodology}

As per Huq et al., (2014), we operationalize social sustainability as being concerned with human rights, health and safety and community. It is well recognized that the management of social sustainability is a challenge for supply chains (Matos and Hall, 2007); a challenge that is exacerbated by the devastating consequences of failure. It is therefore somewhat surprising that research on social sustainability from a SCM perspective is under-developed (Huq et al., 2014) and lags behind that of environmental sustainability research (Marshall et al., 2015b; Moxham and Kauppi, 2014). Because of the importance and far reaching consequences of social sustainability it seems apposite to develop the field further by exploring the assessment of social sustainability in SCM using the theoretical lens of institutional theory. Institutional theory is well developed, yet as the context of social sustainability is not, we will focus on theory testing to allow us to use existing theory to address the research question developed from our a priori review of literature (Ketokivi and Choi, 2014). Thus whilst we are interested in how and why the non-mandatory assessment of social sustainability is adopted by supply chains it must also be noted that the focus on institutional isomorphism has wider implications for management research. 
In examining the institutionalization of social sustainability in SCM we chose to examine voluntary assessment initiatives. As explained, voluntary assessment initiatives in this context are exerting pressure on supply chain actors to adopt socially sustainable practices. Rather than focus on one particular actor in the chain (i.e. first tier suppliers), social sustainability assessment aims to encompass the entire supply chain. An overview of the way in which these types of assessment initiatives operate is included as Figure 1. As Figure 1 illustrates, actors in a supply chain provide performance information to the assessor. This type of information is usually focused on aspects of trading practices as related to social sustainability (e.g. human rights, use of child labor, community development). The social sustainability assessment initiative provides information to supply chain actors about the requirements to become affiliated with the initiative, and subsequently about whether the performance information provided meets these requirements. For complete visibility, it follows that all actors in a supply chain should be engaging with the same assessment initiative; although there is limited evidence to suggest that this is always the case. Consumers receive performance information from the social sustainability assessment initiative in the form of labelling, promotions and annual reports and also feedback on performance to the initiative. Customers also receive information from the media on the performance of different assessment initiatives, and again have the opportunity to feedback.

[insert Figure 1 here]

The assessment of the social sustainability credentials of a supply chain is a relatively new concept and examining assessment initiatives affords us an examination of new forms of 
governance. To develop an understanding of this relatively new landscape we conducted a qualitative study. Qualitative studies enable rich data to be captured and are particularly helpful in developing an understanding of phenomena that have thus far been afforded relatively limited research attention (Voss, 2008). As per studies using a similar research design (e.g. Di Stefano et al., 2015), we firstly acquainted ourselves with social sustainability assessment by making personal contacts with industry experts involved in the development and dissemination of social sustainability assessment, discussing with key academics in the field and attending relevant conferences, seminars and panel discussions. One of the authors had previously worked in southern Ethiopia and has an understanding of social sustainability in the context of coffee farming. By drawing on our acquired knowledge we decided the next step in our study was to conduct interviews with social sustainability focused voluntary assessment initiatives. A database of voluntary assessment initiatives focused on social sustainability does not currently exist. To begin to identify potential initiatives that could be included in the study we drew on work by Hartlieb and Jones (2009) who, in examining UK product labelling initiatives, identified four categories: organic agriculture, fair trade, holistic (combining social and environmental issues) and sustainable management of natural resources. Hartlieb and Jones' study focused on the relationship between ethics and product labelling in supply chains and their category of fair trade mainly relates to issues of international trade, social injustice and poverty. It was this category that appeared most relevant for our study. Hartlieb and Jones identified a total of twenty-six ethical, social and environmental labelling initiatives in the UK, of which seven are focused predominantly on social sustainability. Their findings show how product labelling serves its function as a communication tool, whilst also acting as platform for political discourse and industry best practice. 
Building on Hartlieb and Jones' (2009) categorization, we extended our search beyond the UK to identify relevant initiatives focused on social sustainability that were located anywhere in the world. We used recommendations from the international industry experts with whom we had made earlier contact. We also conducted a detailed digital search of voluntary assessment initiatives where the focus was primarily on social sustainability (rather than economic or environmental sustainability). Sixteen initiatives were identified as focusing on the human rights, health and safety and community development aspects of supply chain trading practices and hence were chosen as appropriate for our study. All were contacted by letter and a follow-up e-mail requesting their participation. Each invitation included a digital link to a short video that we had developed to introduce the researchers, outline the aims of the study and highlight its potential benefits for current practice. Of the sixteen that we contacted five did not reply, one declined and ten agreed to take part.

Semi-structured interviews were conducted with a key actor from each assessment initiative (i.e. directors, programme managers and chief executives). As we wished to understand a relatively new phenomenon, semi-structured interviews afforded the rigor of a structured interview combined with the flexibility to explore topics in more detail relevant to the perspective and interest of the interviewee (Huq et al., 2016). The semi-structured interview questions focused on the history and purpose of the assessor, the ways in which the assessor engaged with supply chain actors (including existing and potential consumers), the ways in which the assessor engaged with other voluntary assessment initiatives, the governance structure of the assessment initiative (including fee structure for those wishing to join), goals of the assessor and barriers to 
engaging with global supply chains. The questions were deliberately broad and allowed us to explore a range of issues important to the interviewee. From initial discussions with representatives of the initiatives, it became clear that some employed very few staff. Conducting multiple interviews within each initiative was seen by some as too resource intensive for them and it was explained that they would be unable to take part in the research. As our aim was to examine as many initiatives as possible, we decided on a single respondent interview approach. Due to the international location of the interviewees, interviews were conducted via telephone or Skype, were conducted in English, generally lasted between 45 minutes to one hour and were recorded. Internal documents (i.e. policy and strategy documents) were shared by the interviewees and we augmented our data with publicly available digital material from the websites of the initiatives where available. An overview of those initiatives that agreed to take part in the study is detailed in Table 1.

[insert Table 1 here]

All of the interview recordings were transcribed verbatim. As we were interested in interpreting the data we used a priori coding categories derived from the literature (Miles and Huberman, 1994). We ensured that the themes were situationally grounded in the assessment of social sustainability in supply chains. Our approach to data analysis is based on Bhakoo and Choi (2013) whereby both authors complete a first round of coding and then discuss their results. We initially each coded two interviews and then met to discuss our results. This discussion confirmed acceptable levels of agreement in our coding, and thus we continued to individually, and in parallel, code the remainder of the transcripts. Once completed, we met again to discuss 
the results and to examine, and reach consensus, regarding any discrepancies. Table 2 provides the coding categories and how these were operationalized for data analysis purposes. For example, comments about encouraging firms to integrate social sustainability into their operations were coded as 'normative pressures' whereas comments about leveraging pressure from consumers was coded as 'coercive pressures.'

[insert Table 2 here]

Finally, in reviewing the secondary material we had gathered we were able to apply the above coding process. This material fell broadly into two categories; material explaining internal processes and procedures (e.g. performance indicators, codes of conduct, audit cycles) or more marketing focused (e.g. firm benefits of adopting social sustainability, case study examples). The material supplemented the primary data and provided a useful background to the initiatives in the study.

\section{Results}

By coding the interviews and specified secondary data as per Table 2 we were able to identify sources of institutional pressure exerted on supply chains by social sustainability focused voluntary assessment initiatives. Through the interview discussions it became clear that all of the initiatives had a track record as sources of institutional pressure as their assessments had been taken up by several organizations and/or entire supply chains, and for many their adoption and usage was growing. For some their influence was largely at a country level (e.g. Initiatives B, C, $\mathrm{G}$ and $\mathrm{H}$ ) and for others it was at an international level (e.g. Initiatives A, D, E, F and G). A 
comparative analysis of the ten initiatives is important in light of our research question and Table 3 provides a summary of the institutional pressures exerted by each of the initiatives in the study. In this section we also present a more comprehensive analysis by drawing on the data collected.

\author{
[insert Table 3 here]
}

\title{
Normative pressures
}

We found limited evidence to suggest that the assessment initiatives were using formal education channels to exert normative pressure on supply chains. There was very limited indication of them pushing their social sustainability agenda through universities or other educational institutions by engaging in collaboration or giving guest lectures. Instead, they appear to have taken a more direct approach to normative pressuring by establishing their own education channels regarding, for example, the education of a pool of auditors. Some initiatives appeared to use auditors that were exclusive whereas others permitted auditors to undertake their particular variant of training and "remain fully independent auditors and work for whoever else they wish, but they will have the training which will allow us to say that we consider them to be sufficiently knowledgeable about our systems to perform audits of our members" (Initiative F). Auditors worked closely with producers (farmers and raw material suppliers often located in the global South), often performing on-site visits and offering formal and informal support. They were described as an expert and an important mechanism for educating supply chains in the practice of social sustainability by many of the initiatives. It is important to note that in all cases the producer paid the auditor directly for their services rather than payment being received via the assessment initiative. This may well elevate the educational status of auditors as perceived by 
producers; auditors are essentially the 'face' of the social sustainability assessment initiative. We saw instances of downstream supply chain actors that had successfully passed an audit placing normative pressure on upstream supply chain actors to adopt similar social sustainability practices. "So they say, well, because we like to monitor you and you have also the [social sustainability assessment initiative] tools to monitor further your supply chain, and if they are involved in the same system, it makes this more coherent, let's say, and easier to follow up" (Initiative J). In addition, informal education for multi-national brands and retailers appeared to be an almost constant activity for Initiatives A, C and G. "We want them to adopt the [social sustainability] agenda on the shelves and on their brand" (Initiative A). Working with brands and retailers was perceived as a way of spreading the message that social sustainability is normative whilst simultaneously seeking to grow the market for socially sustainable products.

Rather than formal education channels, the preferred mechanism was professional networks. Producer networks were in operation across all of the initiatives included in the study. These networks often operated as a two way communication channel whereby the initiative disseminated information to its producers and in turn, the opinion of producers regarding important issues was elicited. "It is very important that our scheme takes producers into account and there is always a dialogue around any changes" (Initiative H). The collaborative development of assessment criteria was a key activity that was often facilitated through producer networks. For example, including producers in dialogue about standard setting was viewed as a normative process by the majority of initiatives in the study. Some initiatives spoke of developing assessment criteria jointly with members (e.g. Initiatives A and F) wherein membership constituted producers and also representatives from the trade sector, retail buyers 
and consumers. Whereas other initiatives were much more explicit about producers being the most important stakeholder in developing measurement criteria (e.g. Initiatives $\mathrm{B}, \mathrm{C}$ and $\mathrm{H}$ ). "Our scheme is not an industrial scheme - it originates from producers" (Initiative C). Regardless of the initiative, including the voice of the producer in the establishment of assessment criteria was a normative activity. The involvement of multiple actors in facilitated professional networks as part of the standard setting process was used as a normative argument for the appropriateness of measuring social sustainability.

\section{Coercive pressures}

Coercive isomorphism can be induced formally or informally by an entity to which a firm is dependent. The assessment bodies' only direct power was campaigning, and even here the pressure most likely comes from the campaigns' influence on consumers who hold the spending power. Patterns and channels of coercive pressures thus mostly centered on indirect influences by the assessment initiatives. The results would indeed suggest that the social sustainability initiatives are using the public to exert powerful change pressures. Some used media channels to raise awareness of the issues in conjunction with grassroots campaigning (Initiatives B, C, G, H, I and J). "Obviously there have been tragedies in supply chains that still make the news. So I think that's another driver for a lot of companies that maybe were not necessarily too awake" (Initiative I). "On a regular basis, I think like four times a year, we also have a newsletter to stakeholders and the media. And it's also through the media we like to inform customers, of course. So this is, let's say, more the proactive way [of exerting coercive pressure]" (Initiative J). Surprisingly few interviewees (only Initiative D) mentioned lobbying and working with governmental organizations to exert coercive pressures on firms to adopt social sustainability. 
Much of the direct coercive pressure was only towards those firms already within the realms of the assessment; once firms had committed to the initiative there were frequent audits, checks for compliance and even a risk of expulsion from the initiative if criteria were not adhered to and/or non-compliances corrected. "Obviously if there is non-compliance with a serious issue they [firms] will fail [the audit]" (Initiative F). “We don't actually allow companies to use our logo unless we have an agreement with them and they have achieved accreditation" (Initiative I). The length of the audit cycle was generally between 1-5 years and initiatives discussed "on-going screening" (Initiative A) and the desire for a broad supply chain view even if not all actors are audited. "The key isn't to having the whole chain audited, [it's] that it [the social sustainability initiative] makes sure there are no invisibilities within the supply [of the product]. And if something did crop up, it would be a certain reference for the next auditor to check. That is how we follow up" (Initiative E). Considerable coercive pressure to comply was focused on the producers in a particular supply chain. "The producer facing side is so critical to our mission and for them [producers] there are many more requirements and more scrutiny in terms of auditing as they are quite high up on our list of risk" (Initiative A). Periodic reports on compliance performance were made public by Initiatives D and I.

\section{Mimetic pressures}

In comparison to normative and coercive pressures, we found less evidence of mimetic pressures being exerted by social sustainability assessment initiatives onto supply chains. Assessment initiatives may place mimetic pressure for social sustainability by convincing powerful firms within industries to adopt particular practices and thus form a benchmark, and by creating 
opportunities for mimicking by enabling the sharing of best practices across firms. "We work with major retailers and target them for switches [to socially sustainable products]" (Initiative G). We found limited examples of such practice, with Initiative $\mathbf{J}$ commenting that due to the proliferation of social sustainability assessment initiatives "it makes it quite difficult to benchmark our system with others" (Initiative J). Interviewees (Initiatives D and J) commented on how they have noticed mimetic pressures working in the area through firms signing up to a particular initiative due to pressures from their supply chain partners. As to their own exertion of mimetic pressures, a variety of approaches including informal peer visits, collaborations with multi-national brands, creating and sharing best practice case studies and only allowing socially sustainable products to be sold in retail outlets were used, yet no generic approach was utilized by all.

\section{Discussion}

Institutional theorists have primarily focused on firms acquiring legitimacy, processes of isomorphism and conformity (Lamin and Zaheer, 2012), with the perspective of the pressureexerting bodies being somewhat neglected. Particularly within economics, as opposed to sociology, the processes leading to institutionalization have been less studied (Zucker, 1987). Within the context of SCM, Kauppi (2013) notes how parties that exert pressure upon companies and supply chains have not been a subject of study. Perhaps the limited attention paid to the origins and channels of institutional pressures is a result of this stream of institutional theory viewing prevalent organizational forms partly as arising from 'rational myths' and shared belief systems (Scott, 1987:497). Yet there are inevitably organizations that attempt to impact these shared belief systems by using particular tactics to make others accept new institutional practices 
(Wijen, 2014). Here we have analyzed one type of such organization, voluntary social sustainability assessment initiatives. Specifically, we posed the following research question: How do social sustainability assessment initiatives exert normative, coercive and mimetic pressures on firms to adopt socially sustainable practices in their supply chains? Overall, the results suggest examples of coercive pressure as the prevalent form used by the assessment initiatives. There was some evidence of the use of normative pressures and limited use of mimetic pressures. Below, we will discuss these findings in more detail and draw comparisons to previous literature. We have synthesized our key findings and present these as Table 4, in which we first detail the key findings in relation to each of the pressures, then the overall observation arising from those findings followed by suggestions for future research avenues.

As the assessment initiatives have options only to penalize those already within the realms of their system, coercive pressures were seen mainly within the functioning of the assessment itself, i.e. risk of expulsion for non-compliance. Marshall et al. (2015b) find that coercive pressures, specifically government/regulatory, are not significant in driving social sustainability adoption in supply chains. Indeed, we also found very limited evidence of the assessment initiatives working with/through governmental organizations to induce coercive pressures for social sustainability. Other forms of coercive pressures are therefore likely to be more important in this context, and thus important aspects to be included in future studies from a firm perspective. Specifically, consumer pressures and the media can be powerful in coercing organizations towards sustainability (Park-Poaps and Rees, 2010) and many of the assessment initiatives in our study were indeed collaborating with media and attempting to influence consumption patterns as a way to increase adoption of the assessments among firms. 
An explanation for the limited exertion of mimetic pressure noted in our study may be due to mimetic pressure being most prevalent in interactions between firms (Raffaelli and Glynn, 2013), whereas coercive and normative pressures relate more closely to interactions between a firm, its environment and its stakeholders. It may therefore be easier for a third party organization, such as those we studied, to initiate coercive and normative pressures rather than those that are mimetic. Alternatively, or complementary, we posit that because social sustainability assessments are not yet mainstream (Moxham and Kauppi, 2014) and, as importantly, not yet sufficiently strongly associated with business competitive advantage within the minds of managers (Peloza, 2009), mimetic pressures are more difficult to induce. As per recent findings, seeking a competitive advantage is a key motivator for firms to adopt social sustainability practices (Marshall et al., 2015b). Within environmental (supply chain) management, we have witnessed an increasing amount of research demonstrating the business benefits of the adoption of 'green' practices (see e.g. Russo and Fouts, 1997; Green et al., 2012), yet the same cannot be said for social sustainability practices; the performance benefits across supply chains are not yet proven. Perhaps inabilities to benchmark (as noted by Initiative J) and/or to unequivocally demonstrate pecuniary gains are hindering the development of mimetic pressures.

Even though we did not see significant evidence of the assessment initiatives using mimetic pressures to induce competitive copying of assessments between firms, we did witness them arguing strongly for the pragmatic legitimacy and business sense of their own assessments; potentially a precursor to mimetic pressures. Institutional theory both implies the benefits of conforming to societal norms as well as the managerial capacity to resist such pressures under 
conditions of ambiguity related to financial gains; incentive mechanisms are needed to ensure compliance (Berrone and Gomez-Mejia, 2009). Recent studies have documented the increase in proliferation of sustainability certifications, particularly within the coffee sector (Ingenbleek and Reinders, 2013; Reinecke et al., 2012). For quality and environmental management systems there are standards that dominate. Yet this is not the case for social sustainability where a variety of norms, codes of conduct and initiatives are present (Castka and Balzarova, 2008). It is argued that the proliferation of social sustainability assessment has led to competition for adoption by multinational organizations in order to reinforce the legitimacy of particular assessment practices (Gereffi et al., 2001). Thus perhaps the motivation to pressure companies derives partly also from the legitimacy/competition of the competing assessment initiatives themselves.

Normative pressures are a result of standards and values that e.g. academic institutions and industry associations put forward (Tate et al., 2014). We ascertained some use of normative pressure, mostly taking the form of training auditors and the use of professional networks. Tate et al. (2014) suggest that managers wanting to adopt environmental initiatives could send employees to engage with various networks and coalitions and we confirm this suggestion, extending it to social sustainability.

New institutions emerge when entities with adequate resources identify an opportunity to realize particular interests that they value highly (DiMaggio, 1988). The voluntary assessment initiatives have identified the opportunity to promote social sustainability as a standard practice into a firm's supply chain practices given the e.g. consumer and media attention around related malpractices in recent years (Huq et al., 2014). We would argue however, that on their own, the 
initiatives lack the adequate resources as referred to by DiMaggio (1988). Our research brings to the fore the use of the three classical forms of institutional pressures by these actors, yet we see the social sustainability assessments instigating institutional pressures more indirectly than directly. They exert coercive pressures through consumers and compliance requirements, normative pressures through auditor training and facilitating producer networks and mimetic pressures through targeting retailers and informal peer visits to diffuse this new form of organization in supply chains. In other words, the institutional pressures exerted on a supply chain appear to operate as a chain themselves; the pressure that a company faces from its supply chain partners or through the media, for example, may be a pressure originated from an assessment initiative. We have offered here just one perspective to the origins of pressures, but based on our findings we recognize this as an important concept for future study. When studying the institutionalization of supply chain practices, it is not enough to only understand the pressures that a company perceives, nor the pressures that one particular type of sustainability actor (here voluntary assessment initiative) emits, but rather to holistically investigate all pressures being emitted directly and indirectly to supply chain actors. Table 4 summarizes these key findings, and based on the observations of both direct and indirect pressures being exerted by the assessment initiatives, we propose the following:

Institutional pressures operate as chains, where entities (here assessment initiatives) with a sustainability agenda will apply coercive, normative and mimetic pressures to companies both directly and indirectly depending on their resources and power to exert such pressures. 
Specifically, given their access to and influence (or lack of both) over firms, initiatives will either coerce companies directly (for firms within the realms of the assessment) or exert coercive, normative or mimetic pressures through other actors in the supply chain, such as retailers or consumers, or through external stakeholders such as the media. This finding also reemphasizes the contextual setting of the assessment initiatives as presented in Figure 1. The assessment initiatives have relationships and contacts with actors across supply chains, and also benefit from the relationships between other actors in putting their agenda forward.

This important proposition from our study underpins our recommendations for further research, and we thus suggest three research questions as primary avenues for further work examining the institutionalization of social sustainability practices, especially voluntary assessment, as

presented in Table 4. Firstly, greater focus should be placed on studying how sustainability actors that are lacking in direct access or influence with companies could use other actors in the chain and/or external stakeholders (e.g. government) to exert institutional pressures around social sustainability. Secondly, it would be valuable to study the paths the pressures take, and how the pressures change and formulate along the way, i.e. when using other parties to indirectly emit pressures, is there a risk of the message becoming distorted? Thirdly, and related, is the question of mapping the paths such pressures take, and understanding the level of intention of each actor in such pressure chains.

\section{Conclusions}

There is a shortage of empirical research on social sustainability in supply chains, including its antecedents (Marshall et al. 2015a). Within SCM, research often takes a deterministic 
perspective, suggesting that external factors have a significant impact on the sustainability choices a manager makes, through pressures to appear legitimate (Marshall et al., 2015a). This has led to a rise in institutional theory oriented research on sustainable SCM, examining how institutional pressures impact the adoption of sustainable practices. However more research has been called for on the 'supply-side factors' of the diffusion process of new practices (Ansari et al., 2010). We have contributed to this literature through our empirical investigation of the role of social sustainability assessment initiatives in institutionalizing said assessments in supply chains.

We witness the assessment initiatives directly, but mainly indirectly via other actors and stakeholders, exerting pressures on companies to adopt social sustainability assessments in their supply chains. Specifically, depending on its position and resources, an assessment initiative will either target a company directly with coercive pressures, or indirectly with coercive, normative and/or mimetic pressures through other actors in the supply chain or external parties such as the media. Based on our study we propose that these institutional pressures thus form a chain of their own. This finding has important implications for how the institutionalization of (socially sustainable) supply chain practices should be studied in the future. Based on these findings, we offer three important future research avenues for sustainable SCM scholars (as detailed in Table 4). The proposed research directions contribute to shaping future social sustainability focused SCM research. Our findings demonstrate the importance of opening up and examining the 'black box' of institutional pressures exerted on supply chains, and understanding the different parties involved in shaping company practices. For example, our findings demonstrate the important role of consumers and media in the chain of institutional 
pressures for social sustainability; these parties are not often (explicitly) included in empirical research regarding the adoption of sustainability practices by companies. Furthermore, given the extensive use of simple proxy or grouped measures of institutional pressures in survey studies in the supply chain field (Kauppi, 2013), our findings suggest that researchers examining the adoption of sustainable SCM practices need to develop a more fine-grained understanding of how companies are being influenced through chains of pressures. Finally, with regard to social sustainability assessment in particular, our findings demonstrate a 'norm' still under development, with assessment initiatives attempting to shape the future of supply chains but unable to do so in isolation, and thus requiring the support of other stakeholders. This finding presents an interesting research opportunity to investigate the development paths such practices take as well as the chance to help form them by, for example, investigating the relative efficiencies of the competing forms.

While our study has a strong theoretical focus, the results do include implications for practice, both for assessment initiatives as well as the companies they target. First, for assessment initiatives, we noted a lack of engagement with 'traditional' education channels such as universities and colleges to introduce normative pressures around social sustainability assessment. We see this as a key development area to focus on in the future, especially as it represents a relatively resource-light option for them. By providing guest lectures, teaching cases and engaging in other types of collaboration with e.g. SCM academics, the assessment initiatives could gain access to and influence the future supply chain decision makers. Second, as our results point to limited opportunities for coercive pressure for the initiatives other than towards the companies already within the realms of assessment, we would also encourage stronger 
advocacy work towards governmental organizations to push social sustainability assessment into a legal requirement for companies. Continuing to exert coercive pressure via consumers and media is encouraged; this could be assisted by making the audit reports more publicly available and visible on their own websites. Third, the variety of approaches noted in the creation of mimetic pressures, such as best practice case studies and brand collaborations, are noted as an important strategy for the future; particularly if efforts are focused on leading (retail) brands that are most likely to be mimicked in addition to rolling out practices across their own supply chains.

For companies, the key practical implication is developing their understanding of the ways in which they are being influenced by third parties. As Kauppi (2013) notes, understanding the origins of institutional pressures can assist companies in finding a better fit between their goals and the tools used to achieve them. Specifically, rather than simply adopting an assessment initiative for the sake of legitimacy, companies should focus on evaluating the different assessments and study the best practice cases put forward to find the best fit with their own supply chain. Furthermore, the auditor training provided by the assessment initiatives could be a resource for companies, if e.g. new buyers with responsibilities in global supply chain management could take part in such courses to better understand the social sustainability issues they are likely to face with their suppliers. Finally, companies already associated with particular assessment initiatives could attempt to use the pressures put forward by the assessment initiatives to promote their own legitimacy: the companies could offer to publicize their own efforts on e.g. the initiatives websites, and help present themselves as the best practice cases. The reporting of 
the credentials regarding their sustainability efforts could be more credible as it is coming from an independent third party.

Our focus was solely within the 'pressure-emitting' parties, the institutional entrepreneurs, in relation to a new governance form, with no data collected from the likely adopters of the new form, i.e. supply chain actors. Such studies, especially within the supply chain domain, are increasing; yet the combination of these stakeholder viewpoints is lacking. In future research, it would thus be worthwhile to investigate the paths of the institutional pressures on the legitimacy of social sustainability in more detail by e.g. longitudinal studies involving several pressureemitting parties, such as the assessment initiatives as well as e.g. consumers, and the pressuretargets, i.e. firms adopting their assessments.

DiMaggio and Powell (1983) call attention to the observation that the three different institutional pressures, while involving different processes, could operate simultaneously. Here we have shown that the parties instituting such pressures do so simultaneously using multiple channels. Additionally, we concur with DiMaggio and Powell (1983) in that the pressures can partly be difficult to empirically distinguish; e.g. the role of peer meetings (among colleagues and among firms) is discussed both within mimetic and normative pressures. We have focused our analysis to examine the perspective of those emitting pressure. We are interested in ascertaining whether the aim was to institute a desire to copy successful (early) adopters or to generate the perception that a course of action is the 'normal' requirement. Whether the actual adoption of practices happens through mimetic or normative perception by the recipients of the pressures is of course 
another perspective, and one that has been studied by several authors across numerous contexts already (see e.g. Zhu and Sarkis, 2007; Bhakoo and Choi, 2013; Glover et al., 2014).

Whilst we view the findings of our study as important, we must also acknowledge its methodological limitations. Due to the limited resources of the assessment initiatives it was undesirable to interview multiple respondents from each initiative. We therefore rely on the views expressed by one individual as representative. We also recognize the relatively small sample size. As noted previously, it was challenging to identify assessment initiatives focused primarily on social sustainability, and of those that we did find, not all chose to take part in our study. Further work may be able to address these shortcomings; however seeking multiple respondents may limit the sample further to include only those initiatives with sufficient resources. Despite these shortcomings, we believe that our research offers interesting, multiple viewpoints to institutional pressures in this developing field that may serve as a platform for further work in this important area.

\section{References}

Adebanjo, D., Ojadi, F., Laosirihongthong, T. and Tickle, M. (2013),"A case study of supplier selection in developing economies: a perspective on institutional theory and corporate social responsibility", Supply Chain Management: An International Journal, Vol. 18 No 5, pp. $553-566$.

Ansari, S. M., Fiss, P. C., and Zajac, E. J. (2010), "Made to fit: How practices vary as they diffuse", Academy of Management Review, Vol. 35 No. 1, pp. 67-92.

Bansal, P. and Roth, A. (2000), "Why companies go green: A model of ecological responsiveness", Academy of Management Journal, Vol. 43 No. 4, pp. 717-736. 
Berrone, P. and Gomez-Mejia, L. R. (2009), "Environmental performance and executive compensation: An integrated agency-institutional perspective", Academy of Management Journal, Vol. 52 No. 1, pp. 103-126.

Bhakoo, V. and Choi, T. (2013), "The iron cage exposed: Institutional pressures and heterogeneity across the healthcare supply chain", Journal of Operations Management, Vol. 31 No. 6, 432-449.

Bruton, G., Ahlstrom, D. and Li, H. (2010), "Institutional theory and entrepreneurship: Where are we now and where do we need to move in th future?", Entrepreneurship Theory and Practice, Vol. 34 No. 3, pp. 421-440.

Burchell, J. and Cook, J. (2013), “CSR, co-optation and resistance: The emergence of a new agonistic relations between business and civil society", Journal of Business Ethics, Vol. 115 No. 4, pp. 741-754.

Castka, P. and Balzarova, M. A. (2008), "ISO 26000 and supply chains - On the diffusion of the social responsibility standard", International Journal of Production Economics, Vol. 111 No. 2, pp. 274-286.

Di Stefano, G., King, A., and Verona, G. (2015), "Sanctioning in the wild: Rational calculus and retributive instincts in gourmet cuisine", Academy of Management Journal, Vol. 58 No. 3, pp. 906-931.

DiMaggio, P. and Powell, W. W. (1983), "The iron cage revisited; collective rationality and institutional isomorphism in organizational fields", American Sociological Review, Vol. 48 No 2, pp. 147-160.

DiMaggio, P. (1988), "Interest and agency in institutional theory". In L. G. Zucker (Ed.), Institutional Problems and Organizations: Culture and Environment, Cambridge, MA.: Ballinger, pp. 3-20..

Gereffi, G., Humphrey, J., and Sturgeon, T. (2005), "The governance of global value chains", Review of International Political Economy, Vol. 12 No. 1, pp. 78-104.

Gereffi, G., Garcia-Johnson, R., and Sasser, E. (2001), “The NGO-Industrial Complex”, Foreign Policy, Vol. July/August, pp. 56-65.

Giovannucci, D. and Ponte, S. (2005), "Standards as a new form of social contract? Sustainability initiatives in the coffee industry", Food Policy, Vol. 30 No. 3, pp. 284-301. 
Glover, J. L., Champion, D., Daniels, K. J. and Dainty, A. J. D. (2014), “An Institutional Theory perspective on sustainable practices across the dairy supply chain", International Journal of Production Economics, Vol. 152, pp. 102-111.

González, P., Sarkis, J., and Adenso-Diaz, B. (2008), "Environmental management system certification and its influence on corporate practices: Evidence from the automotive industry", International Journal of Operations and Production Management, Vol. 28 No. 11, pp. 1021-1041.

Grappi, S., Romani, S., and Bagozzi, R. P. (2013), "Consumer response to corporate irresponsible behaviour: Moral emotions and virtues", Journal of Business Research, Vol. 66, No. 10, pp. 1029-1042.

Green Jr, K., Zelbst, P., Meacham, J. and Bhadauria, V. (2012), "Green supply chain management practices: Impact on performance", Supply Chain Management: An International Journal, Vol. 17 No. 3, pp. 290-305.

Grewal, R. and Dharwadkar, R. (2002), "The role of the institutional environment in marketing channels", Journal of Marketing, Vol. 66 No. 3, pp. 82-97.

Grosvold, J., Hoejmose, S. and Roehrich, J. (2014), "Squaring the circle", Supply Chain Management: An International Journal, Vol. 19 No. 3, pp. 292 - 305.

Guler, I., Guillen, M., and MacPherson, J. (2002), "Global competition, institutions, and the diffusion of organizational practices: The international spread of the ISO 9000 quality certificates", Administrative Science Quarterly, Vol. 47 No. 2, pp. 207-232.

Hartlieb, S. and Jones, B. (2009), "Humanising business through ethical labelling: Progress and paradoxes in the UK", Journal of Business Ethics, Vol. 88 No. 3, pp. 583-600.

Haunschild, P. and Miner, A. (1999), "Modes of interorganizational imitation: The effects of outcome salience and uncertainty", Administrative Science Quarterly, Vol. 42 No. 3, pp. 472-500.

Hayagreeva, R. and Sivakumar, K. (1999), "Institutional sources of boundary-spanning structures: The establishment of investor relations departments in the Fortune 500 industrials", Organization Science, Vol. 10 No. 1, pp. 27-42.

Heugens, P. and Lander, M. (2009), "Structure! Agency! (and other quarrels): A meta-analysis of institutional theories of organization", Academy of Management Journal, Vol. 52, No. 1, pp. 61-85. 
Huq, F., Stevenson, M., and Zorzini, M. (2014) ,"Social sustainability in developing country suppliers", International Journal of Operations and Production Management, Vol. 34 No. 5, pp. 610-638.

Huq, F., Chowdhury, I. and Klassen, R. (2016), "Social management capabilities of multinational buying firms and their emerging market suppliers: An exploratory study of the clothing industry", Journal of Operations Management, Vol. 46, pp. 19-37.

Ingenbleek, P. and Reinders, M. (2013), "The development of a market for sustainable coffee in the Netherlands: Rethinking the contribution of Fair Trade", Journal of Business Ethics, Vol. 113 No. 3, pp. 461-474.

Klein, J. G., Smith, C. N., and John, A. (2004), "Why we boycott: Consumer motivations for boycott participation”, Journal of Marketing, Vol. 68, No. 3. pp. 92-109.

Kauppi, K. (2013), "Extending the use of institutional theory in operations and supply chain management research: Review and research suggestions", International Journal of Operations and Production Management, Vol. 33 No. 10, pp. 1318-1345.

Ketokivi, M. and Choi, T. (2014), "Renaissance of case research as a scientific method", Journal of Operations Management, Vol. 32 No. 5, pp. 232-240.

Lamin, A. and Zaheer, S. (2012), "Wall Street vs. Main Street: Firm strategies for defending legitimacy and their impact on different stakeholders", Organization Science, Vol. 23 No. 1, pp. 47-66.

Maclean, T. and Benham, M. (2010), "The dangers of decoupling: The relationship between compliance programs, legitimacy perceptions, and institutionalizaed misconduct", Academy of Management Journal, Vol. 53, No. 6, pp. 1499-1520.

Marshall, D., McCarthy, L., Claudy, M. and McGrath, P. (in press), "Piggy in the middle: How direct customer power affect first-tier suppliers' adoption of socially responsible procurement practice and performance", Journal of Business Ethics, DoI: 10.007/s10551016-3387-0

Marshall, D., McCarthy, L., McGrath, P. and Claudy, M. (2015a),"Going above and beyond: how sustainability culture and entrepreneurial orientation drive social sustainability supply chain practice adoption", Supply Chain Management: An International Journal, Vol. 20 No. 4 , pp. $434-454$. 
Marshall, D., McCarthy, L., Heavey, C. and McGrath, P. (2015b), "Environmental and social supply chain management sustainability practices: Construct development and measurement", Production Planning and Control, Vol. 26 No. 8, pp. 673-690.

Matos, S. and Hall, J. (2007), "Integrating sustainable development in the supply chain: The case of life cycle assessment in oil and gas and agricultural biotechnology", Journal of Operations Management, Vol. 25 No. 6, pp. 1083-1102.

Meyer, J. and Rowan, B. (1977), "Institutionalized organizations: Formal structure as myth and ceremony", American Journal of Sociology, Vol. 83 No. 2, pp. 340-363.

Miles, H. and Huberman, M. (1994). Qualitative data analysis: A sourcebook: Sage.

Morali, O. and Searcy, C. (2013), "A review of sustainable supply chain practices in Canada", Journal of Business Ethics, Vol. 117 No. 3, pp. 636-658.

Moxham, C. and Kauppi, K. (2014), "Using organizational theories to further our understanding of socially sustainable supply chains: The case of fair trade", Supply Chain Management: An International Journal, Vol. 19, No. 4, pp. 413-420.

Okhmatovskiy, I. and David, R. J. (2012), "Setting your own standards: Internal corporate governance codes as a response to institutional pressure", Organization Science, Vol. 23 No. 1, pp. 155-176.

Park-Poaps, H. and Rees, K. (2010), "Stakeholder forces of socially responsible supply chain management orientation", Journal of Business Ethics, Vol. 92 No. 2, pp. 305-322.

Peloza, J. (2009), "The challenge of measuring financial impacts from investment in corporate social performance", Journal of Management, Vol. 35 No. 6, pp. 1518-1541.

Perez-Aleman, P. (2011), "Collective learning in global diffusion: Spreading quality standards in a developing country cluster", Organization Science, Vol. 22 No. 1, pp. 173-189.

Raffaelli, R. and Glynn, M. A. (2013), "Turnkey or tailored? Relational pluralism, institutional complexity, and the organizational adoption of more or less customized practices", Academy of Management Journal, Vol. 57 No. 2, pp. 541-562.

Rao, P. and Holt, D. (2005), "Do green supply chains lead to competitiveness and economic performance?", International Journal of Operations and Production Management, Vol. 25 No. 9, pp. 898-916. 
Reinecke, J., Manning, S., and von Hagen, O. (2012), "The emergence of a standards market: Multiplicity of sustainability standards in the global coffee industry", Organization Studies, Vol. 33 No. 5-6, pp. 791-814.

Russell, C., Russell, D. and Honea, H. (2016), "Corporate social responsibility failures: How do consumers respond to corporate violations of implied social contracts?", Journal of Business Ethics, Vol. 136, No. 4, pp. 759-773.

Russo, M. and Fouts, P. (1997), "A resource-based perspective on corporate environmental performance and profitability", Academy of Management Journal, Vol. 40 No. 3, pp. 534559.

Sancha, C., C., G., Sierra, V., and Kazeminia, A. (2015), "Does implementing social supplier development practices pay off? "Supply Chain Management: An International Journal, Vol. 20 No. 4, pp. 389-403.

Scott, W. (1987), "The adolescence of institutional theory", Administrative Science Quarterly, Vol. 32 No. 4, pp. 493-511.

Tate, W., Ellram, L., and Dooley, K. (2014), "The impact of transaction costs and institutional pressure on supplier environmental practices", International Journal of Physical Distribution and Logistics Management, Vol. 44 No. 5, pp. 353-372.

Vachon, S. and Klassen, R. D. (2008), "Environmental management and manufacturing performance: The role of collaboration in the supply chain", International Journal of Production Economics, Vol. 111 No. 2, pp. 299-315.

Voss, C. (2008), "Case research in operations management," in Karlsson, C. (Ed.) Researching Operations Management, Routledge, New York, pp 162-195.

Weerakkody, V., Dwivedi, Y. K., and Irani, Z. (2009), "The diffusion and use of institutional theory: A cross-disciplinary longitudinal literature survey", Journal of Information Technology, Vol. 24 No. 4, pp. 354-368.

Wijen, F. (2014), "Means versus ends in opaque institutional fields: Trading off compliance and achievement in sustainability standard adoption", Academy of Management Review, Vol. 39, No. 3, pp. 302-323.

Wu, G., Ding, J., and Chen, P. (2012), "The effects of GSCM drivers and institutional pressures on GSCM practices in Taiwan's textile and apparel industry", International Journal of Production Economics, Vol. 135 No. 2, pp. 618-636. 
Yawar, S. and Seuring, S. (2017), "Management of social issues in supply chains: A literature review exploring social issues, actions and performance outcomes", Journal of Business Ethics, Vol. 141, No. 3, pp. 621-643.

Zhu, Q. and Sarkis, J. (2007), "The moderating effects of institutional pressures on emergent green supply chain practices and performance", International Journal of Production Research, Vol. 45 No. 18, pp. 4333-4356.

Zhu, Q., Sarkis, J., and Lai, K. (2013), "Institutional-based antecedents and performance outcomes of internal and external green supply chain management practices", Journal of Purchasing and Supply Management, Vol. 19 No. 2, pp. 106-117.

Zorzini, M., Hendry, L., Huq, F., and Stevenson, M. (2015), "Socially responsible sourcing: Reviewing the literature and its use of theory", International Journal of Operations and Production Management, Vol. 35 No. 1, pp. 60-109.

Zucker, L. 1987. Institutional theories of organization. Annual Review of Sociology, Vol. 13, pp. 443-46 
Figures and Tables

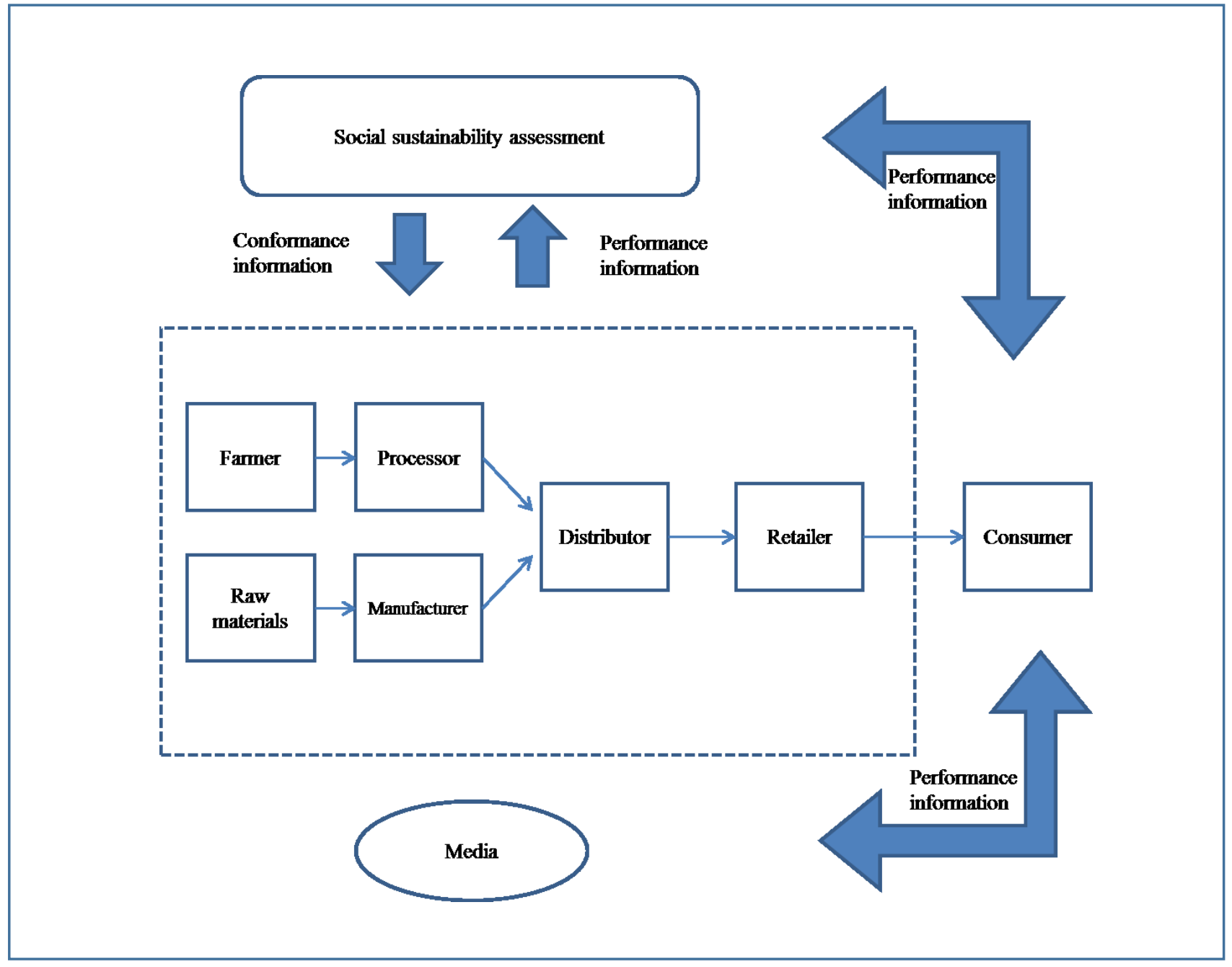

Figure 1 - Relationship between supply chain, assessment initiative and other actors 


\begin{tabular}{|c|c|c|c|c|}
\hline $\begin{array}{l}\text { Social } \\
\text { Sustainability } \\
\text { Assessment } \\
\text { Initiative }\end{array}$ & $\begin{array}{l}\text { Role of } \\
\text { Interviewee }\end{array}$ & $\begin{array}{l}\text { Key Principles of } \\
\text { Initiative }\end{array}$ & Products Assessed & $\begin{array}{l}\text { Location of } \\
\text { Head Office }\end{array}$ \\
\hline A & $\begin{array}{l}\text { Director of } \\
\text { Standards and } \\
\text { Pricing }\end{array}$ & $\begin{array}{l}\text { International focus, } \\
\text { agreed minimum } \\
\text { pricing, charter of } \\
\text { principles }\end{array}$ & $\begin{array}{l}\text { Bananas, cocoa, } \\
\text { coffee, cotton, flowers, } \\
\text { fresh fruit, honey, } \\
\text { gold, fruit juices, rice, } \\
\text { spice, herbs, sports } \\
\text { balls, sugar, tea, wine }\end{array}$ & Europe \\
\hline B & $\begin{array}{l}\text { Assessment Co- } \\
\text { ordinator }\end{array}$ & $\begin{array}{l}\text { Development of } \\
\text { social sustainability } \\
\text { of small producers } \\
\text { based in Latin } \\
\text { America and } \\
\text { Caribbean through } \\
\text { training, product } \\
\text { promotion and } \\
\text { certification }\end{array}$ & $\begin{array}{l}\text { Oil, nuts, seeds, sugar, } \\
\text { bananas, cocoa, fresh } \\
\text { fruit, dried fruit, } \\
\text { juices, coffee, honey, } \\
\text { wine, quinoa, } \\
\text { handicrafts, tea, } \\
\text { flowers }\end{array}$ & Latin America \\
\hline $\mathrm{C}$ & $\begin{array}{l}\text { Head of } \\
\text { Commercial } \\
\text { Relations }\end{array}$ & $\begin{array}{l}\text { National focus to } \\
\text { raise awareness of } \\
\text { certified products, } \\
\text { connecting certified } \\
\text { producers to retailers, } \\
\text { agreed minimum } \\
\text { pricing }\end{array}$ & $\begin{array}{l}\text { Coffee, flowers, wine, } \\
\text { beer, fruit, cotton, tea, } \\
\text { cocoa, chocolate, } \\
\text { sugar, honey, rice, } \\
\text { quinoa, cosmetics, } \\
\text { spices, herbs, oils, } \\
\text { walnut, dried fruit, } \\
\text { sports balls }\end{array}$ & Europe \\
\hline $\mathrm{D}$ & $\begin{array}{l}\text { Assessment } \\
\text { Consultant }\end{array}$ & $\begin{array}{l}\text { International focus } \\
\text { on promoting social } \\
\text { sustainability } \\
\text { through development } \\
\text { of labor standards }\end{array}$ & $\begin{array}{l}\text { Clothing, textiles, } \\
\text { leather, footwear }\end{array}$ & Europe \\
\hline $\mathrm{E}$ & $\begin{array}{l}\text { Director of } \\
\text { Operations }\end{array}$ & $\begin{array}{l}\text { International focus } \\
\text { on certification } \\
\text { against defined social } \\
\text { sustainability } \\
\text { standards }\end{array}$ & $\begin{array}{l}\text { Bananas, cane sugar, } \\
\text { cocoa, coffee, dried } \\
\text { fruit, dried vegetables, } \\
\text { flowers, fruit, fonio, } \\
\text { fresh fruit, fruit juices, } \\
\text { gold, herbs, honey, } \\
\text { nuts, oilseeds, quinoa, } \\
\text { rice, spices }\end{array}$ & Europe \\
\hline $\mathrm{F}$ & Chief Executive & $\begin{array}{l}\text { International supply } \\
\text { chain focus on } \\
\text { certification against } \\
\text { defined social } \\
\text { sustainability } \\
\text { standards }\end{array}$ & Handicrafts, clothing & Europe \\
\hline
\end{tabular}




\begin{tabular}{|l|l|l|l|l|}
\hline G & $\begin{array}{l}\text { Senior Research } \\
\text { and Impact Advisor }\end{array}$ & $\begin{array}{l}\text { National focus on } \\
\text { certification of } \\
\text { socially sustainable } \\
\text { products, agreed } \\
\text { minimum pricing, } \\
\text { government lobbying }\end{array}$ & $\begin{array}{l}\text { Bananas, chocolate, } \\
\text { gold, coffee, cotton, } \\
\text { flowers, sugar, tea, } \\
\text { wine }\end{array}$ & Europe \\
\hline $\mathrm{H}$ & Executive Director & $\begin{array}{l}\text { National focus on } \\
\text { certification of small } \\
\text { producers, agreed } \\
\text { minimum pricing }\end{array}$ & $\begin{array}{l}\text { Sugar, handicrafts, } \\
\text { bananas, coffee, cocoa, } \\
\text { banana/plantain chips, } \\
\text { fruit juices, jams, } \\
\text { herbs, honey, quinoa }\end{array}$ & Latin America \\
\hline I & $\begin{array}{l}\text { Accreditation } \\
\text { Programme } \\
\text { Manager }\end{array}$ & $\begin{array}{l}\text { International focus } \\
\text { on promoting social } \\
\text { sustainability } \\
\text { through development } \\
\text { of labor standards }\end{array}$ & $\begin{array}{l}\text { Coffee, cocoa, } \\
\text { footwear }, \text { clothing, }\end{array}$ & USA \\
\hline J & $\begin{array}{l}\text { International supply } \\
\text { chain focus on } \\
\text { certification against } \\
\text { defined social } \\
\text { sustainability } \\
\text { standards }\end{array}$ & $\begin{array}{l}\text { Electronics, textiles. } \\
\text { clothing, footwear. }\end{array}$ & Europe \\
\hline
\end{tabular}

Table 1 - Overview of study participants

\begin{tabular}{|c|c|}
\hline Description & Coding Category \\
\hline $\begin{array}{l}\text { Comments about appropriateness of social sustainability } \\
\text { standards/principles }\end{array}$ & \multirow[t]{6}{*}{ Normative pressures } \\
\hline $\begin{array}{l}\text { Comments about including member firms and their employees in the } \\
\text { development of standards/principles }\end{array}$ & \\
\hline $\begin{array}{l}\text { Comments about encouraging firms to integrate social sustainability into } \\
\text { operations }\end{array}$ & \\
\hline Comments about collaborating with universities and colleges & \\
\hline Comments about training auditors to diffuse social standards & \\
\hline Comments about mainstreaming of social sustainability & \\
\hline Comments about enforcing compliance of members to assessment process & \multirow[t]{7}{*}{ Coercive pressures } \\
\hline $\begin{array}{l}\text { Comments about social sustainability assessment being the responsible } \\
\text { course of action }\end{array}$ & \\
\hline Comments about leveraging bottom up pressure from consumers & \\
\hline Comments about engaging advocacy/campaigning groups & \\
\hline Comments about eliciting support from government agencies & \\
\hline Comments about creating a public discourse around social justice & \\
\hline $\begin{array}{l}\text { Comments about failure to comply with standards resulting in expulsion } \\
\text { from scheme }\end{array}$ & \\
\hline Comments about peer pressure to conform to standards & \multirow[t]{4}{*}{ Mimetic pressures } \\
\hline Comments about use of communication channels and peer visits & \\
\hline $\begin{array}{l}\text { Comments about targeting well-recognized organizations to adopt social } \\
\text { sustainability }\end{array}$ & \\
\hline Comments about use of success stories & \\
\hline
\end{tabular}

Table 2 - Description of coding categories 


\begin{tabular}{|c|c|c|c|c|c|c|c|c|c|c|}
\hline & Initiative A & Initiative $\mathrm{B}$ & Initiative $\mathrm{C}$ & Initiative D & $\begin{array}{l}\text { Initiative } \\
\mathrm{E}\end{array}$ & Initiative $\mathrm{F}$ & Initiative $\mathrm{G}$ & Initiative $\mathrm{H}$ & Initiative I & Initiative $\mathrm{J}$ \\
\hline $\begin{array}{l}\text { Normative } \\
\text { pressure } \\
\text { exerted }\end{array}$ & $\begin{array}{l}\text { Social } \\
\text { sustainability } \\
\text { criteria } \\
\text { developed } \\
\text { through } \\
\text { dialogue with } \\
\text { members } \\
\text { Diffusion of } \\
\text { standards } \\
\text { through } \\
\text { owned audit } \\
\text { organization } \\
\text { and networks } \\
\text { of producers } \\
\text { Education on } \\
\text { risk based } \\
\text { approach to } \\
\text { auditing } \\
\text { provided to } \\
\text { organizations } \\
\text { Education on } \\
\text { reporting } \\
\text { mechanisms } \\
\text { delivered } \\
\text { internationally }\end{array}$ & $\begin{array}{l}\text { Social } \\
\text { sustainability } \\
\text { criteria } \\
\text { developed } \\
\text { through } \\
\text { dialogue with } \\
\text { small scale } \\
\text { producers } \\
\text { Diffusion of } \\
\text { standards } \\
\text { through } \\
\text { national small } \\
\text { scale producer } \\
\text { networks } \\
\text { Education on } \\
\text { quality } \\
\text { control good } \\
\text { practice } \\
\text { delivered } \\
\text { internationally }\end{array}$ & $\begin{array}{l}\text { Social } \\
\text { sustainability } \\
\text { criteria } \\
\text { developed } \\
\text { through } \\
\text { dialogue with } \\
\text { members } \\
\text { Strategic } \\
\text { focus on } \\
\text { mainstreaming } \\
\text { social } \\
\text { sustainability } \\
\text { using } \\
\text { professional } \\
\text { networks }\end{array}$ & $\begin{array}{l}\text { Education on } \\
\text { socially } \\
\text { sustainable } \\
\text { supply chain } \\
\text { management } \\
\text { delivered } \\
\text { internationally } \\
\text { Social } \\
\text { sustainability } \\
\text { criteria } \\
\text { developed } \\
\text { through } \\
\text { dialogue with } \\
\text { members } \\
\text { Diffusion of } \\
\text { standards } \\
\text { through } \\
\text { owned audit } \\
\text { organization }\end{array}$ & & $\begin{array}{l}\text { Social } \\
\text { sustainability } \\
\text { criteria } \\
\text { developed } \\
\text { through } \\
\text { dialogue with } \\
\text { members } \\
\text { Delivers } \\
\text { education to } \\
\text { independent } \\
\text { auditors } \\
\text { internationally } \\
\text { Promotes } \\
\text { dialogue and } \\
\text { interaction } \\
\text { through } \\
\text { learning } \\
\text { networks }\end{array}$ & $\begin{array}{l}\text { Dialogue with } \\
\text { multi-national } \\
\text { retail networks } \\
\text { Interaction } \\
\text { through } \\
\text { networks of } \\
\text { producers } \\
\text { Singular and } \\
\text { unified } \\
\text { approach to } \\
\text { social } \\
\text { sustainability } \\
\text { education } \\
\text { across } \\
\text { organization } \\
\text { Strategic focus } \\
\text { on } \\
\text { mainstreaming } \\
\text { social } \\
\text { sustainability } \\
\text { using } \\
\text { professional } \\
\text { networks }\end{array}$ & $\begin{array}{l}\text { Social } \\
\text { sustainability } \\
\text { criteria } \\
\text { developed } \\
\text { through } \\
\text { dialogue } \\
\text { with } \\
\text { producers } \\
\text { Diffusion of } \\
\text { standards } \\
\text { through } \\
\text { producer, } \\
\text { trade and } \\
\text { consumer } \\
\text { networks }\end{array}$ & $\begin{array}{l}\text { Social } \\
\text { sustainability } \\
\text { criteria } \\
\text { developed } \\
\text { through } \\
\text { dialogue } \\
\text { with } \\
\text { business, } \\
\text { university } \\
\text { and civil } \\
\text { society } \\
\text { organization } \\
\text { networks }\end{array}$ & $\begin{array}{l}\text { Social } \\
\text { sustainability } \\
\text { criteria } \\
\text { developed } \\
\text { through } \\
\text { dialogue with } \\
\text { members } \\
\text { Interaction } \\
\text { through } \\
\text { networks of } \\
\text { producers } \\
\text { Delivers } \\
\text { education to } \\
\text { independent } \\
\text { auditors } \\
\text { internationally }\end{array}$ \\
\hline
\end{tabular}




\begin{tabular}{|c|c|c|c|c|c|c|c|c|c|c|}
\hline & Initiative $\mathrm{A}$ & Initiative $\mathrm{B}$ & Initiative $\mathrm{C}$ & Initiative D & Initiative $\mathrm{E}$ & Initiative $\mathrm{F}$ & Initiative $\mathrm{G}$ & Initiative $\mathrm{H}$ & Initiative I & Initiative $\mathrm{J}$ \\
\hline $\begin{array}{l}\text { Coercive } \\
\text { pressure } \\
\text { exerted }\end{array}$ & $\begin{array}{l}\text { De- } \\
\text { certification } \\
\text { as a result of } \\
\text { non- } \\
\text { compliance } \\
\text { to procedures } \\
\text { Promotion of } \\
\text { the adoption } \\
\text { of } \\
\text { certification } \\
\text { linked to } \\
\text { trade justice } \\
\text { All producers } \\
\text { must firstly } \\
\text { adhere to } \\
\text { producer } \\
\text { standards and } \\
\text { then to } \\
\text { product } \\
\text { standards } \\
\text { Multiple } \\
\text { stakeholders } \\
\text { involved in } \\
\text { audit cycle to } \\
\text { ensure full } \\
\text { supply chain } \\
\text { adoption of } \\
\text { standards } \\
\text { On-going } \\
\text { verification } \\
\text { of audit data } \\
\text { to ensure } \\
\text { validity of } \\
\text { socially } \\
\text { sustainable } \\
\text { status }\end{array}$ & $\begin{array}{l}\text { Awareness } \\
\text { raising } \\
\text { through } \\
\text { social } \\
\text { networks, } \\
\text { websites } \\
\text { and } \\
\text { bulletins }\end{array}$ & $\begin{array}{l}\text { Works in } \\
\text { partnership } \\
\text { with towns } \\
\text { and } \\
\text { universities }\end{array}$ & $\begin{array}{l}\text { Lobbies } \\
\text { governments } \\
\text { to improve } \\
\text { the labor } \\
\text { practices } \\
\text { across supply } \\
\text { chains } \\
\text { In some } \\
\text { countries } \\
\text { certification } \\
\text { is compulsory } \\
\text { Encourage } \\
\text { manufacturers } \\
\text { to volunteer } \\
\text { to engage } \\
\text { with } \\
\text { certification } \\
\\
\text { Provides } \\
\text { support for } \\
\text { governments } \\
\text { to implement } \\
\text { international } \\
\text { social } \\
\text { sustainability } \\
\text { standards }\end{array}$ & $\begin{array}{l}\begin{array}{l}\text { Continuous } \\
\text { checks for } \\
\text { compliance } \\
\text { Different } \\
\text { social } \\
\text { sustainability } \\
\text { criteria } \\
\text { developed } \\
\text { for producers } \\
\text { and trade } \\
\text { organizations } \\
\text { that must be } \\
\text { adhered to } \\
\text { Emphasis on } \\
\text { ensuring } \\
\text { visibility } \\
\text { across } \\
\text { supply } \\
\text { chains } \\
\text { Surveys } \\
\text { conducted to } \\
\text { monitor } \\
\text { compliance }\end{array} \\
\text { Annual } \\
\text { audits on } \\
\text { supply chain } \\
\text { conducted } \\
\text { Action plan } \\
\text { for any } \\
\text { corrective } \\
\text { action } \\
\text { required }\end{array}$ & $\begin{array}{l}\begin{array}{l}\text { Explicit } \\
\text { expectation } \\
\text { of full } \\
\text { commitment } \\
\text { to social } \\
\text { sustainability } \\
\text { compliance } \\
\text { Continuous } \\
\text { checks for } \\
\text { compliance } \\
\text { Action plan } \\
\text { for any } \\
\text { corrective } \\
\text { action } \\
\text { required } \\
\text { Unable to } \\
\text { use the } \\
\text { certification } \\
\text { label until } \\
\text { fully } \\
\text { compliant }\end{array} \\
\text { Audits on } \\
\text { supply chain } \\
\text { conducted }\end{array}$ & $\begin{array}{l}\text { National } \\
\text { organizations } \\
\text { build and } \\
\text { sustain market } \\
\text { for socially } \\
\text { sustainable } \\
\text { products in a } \\
\text { particular } \\
\text { country } \\
\text { Direct } \\
\text { grassroots } \\
\text { campaigning } \\
\text { network } \\
\text { operating } \\
\text { through } \\
\text { schools, } \\
\text { churches, } \\
\text { towns and local } \\
\text { groups } \\
\text { Focus on } \\
\text { public } \\
\text { engagement } \\
\text { from business } \\
\text { to consumer } \\
\text { and through } \\
\text { political parties } \\
\text { and NGOs } \\
\text { All members of } \\
\text { supply chain } \\
\text { must be } \\
\text { certified } \\
\text { Work with } \\
\text { campaigning } \\
\text { groups to } \\
\text { encourage } \\
\text { debate }\end{array}$ & $\begin{array}{l}\begin{array}{l}\text { Continuous } \\
\text { checks for } \\
\text { compliance }\end{array} \\
\text { Awareness } \\
\text { raising } \\
\text { through } \\
\text { social } \\
\text { networks, } \\
\text { websites } \\
\text { and } \\
\text { bulletins } \\
\text { Emphasis } \\
\text { on ensuring } \\
\text { that all } \\
\text { members of } \\
\text { a supply } \\
\text { chain are } \\
\text { certified }\end{array}$ & $\begin{array}{l}\text { Explicit } \\
\text { expectation of } \\
\text { full } \\
\text { commitment to } \\
\text { social } \\
\text { sustainability } \\
\text { compliance } \\
\text { Continuous } \\
\text { checks for } \\
\text { compliance } \\
\text { Action plan for } \\
\text { any corrective } \\
\text { action required } \\
\text { with explicit } \\
\text { timeframe } \\
\text { Unable to use } \\
\text { the } \\
\text { certification } \\
\text { label until fully } \\
\text { compliant } \\
\text { Audits on } \\
\text { supply chain } \\
\text { conducted } \\
\text { Explicit about } \\
\text { how } \\
\text { purchasing } \\
\text { decisions often } \\
\text { made on } \\
\text { socially } \\
\text { sustainability } \\
\text { certification } \\
\text { Certification } \\
\text { reports } \\
\text { published on }\end{array}$ & 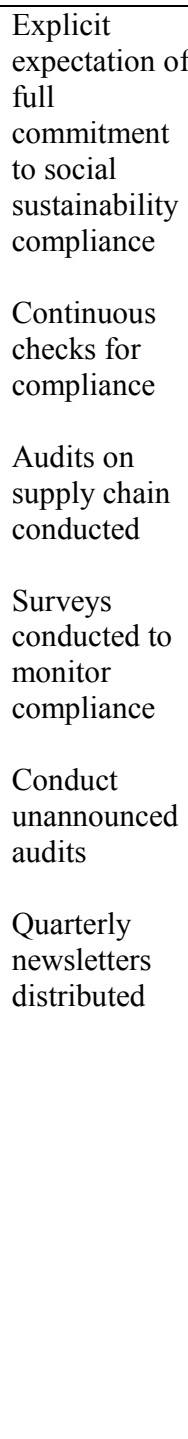 \\
\hline
\end{tabular}




\begin{tabular}{|c|c|c|c|c|c|c|c|}
\hline & & & & & 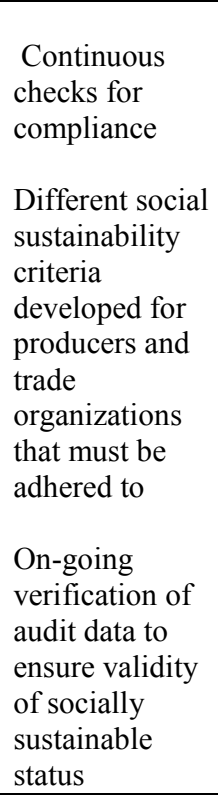 & website & \\
\hline $\begin{array}{l}\text { Mimetic } \\
\text { pressure } \\
\text { exerted }\end{array}$ & $\begin{array}{l}\text { Strategic } \\
\text { focus on the } \\
\text { adoption of } \\
\text { the } \\
\text { certification } \\
\text { logo by retail } \\
\text { outlets and } \\
\text { producers }\end{array}$ & $\begin{array}{l}\text { Products sold } \\
\text { through } \\
\text { outlets that } \\
\text { only stock } \\
\text { fairly traded } \\
\text { goods }\end{array}$ & $\begin{array}{l}\text { Highlights } \\
\text { how } \\
\text { organizations } \\
\text { sign up to the } \\
\text { accreditation } \\
\text { because of } \\
\text { pressure from } \\
\text { supply chain } \\
\text { organizations } \\
\text { already } \\
\text { accredited }\end{array}$ & $\begin{array}{l}\text { Optional } \\
\text { peer visits by } \\
\text { certified } \\
\text { organizations } \\
\text { encouraged }\end{array}$ & $\begin{array}{l}\text { Promotes } \\
\text { socially } \\
\text { sustainable } \\
\text { certification } \\
\text { status of } \\
\text { multinational } \\
\text { branded } \\
\text { products } \\
\text { Builds } \\
\text { platforms to } \\
\text { promote } \\
\text { alliances and } \\
\text { collaboration } \\
\text { between peer } \\
\text { organizations }\end{array}$ & 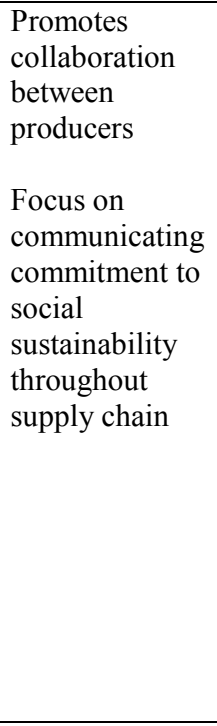 & $\begin{array}{l}\text { Completed } \\
\text { audit reports } \\
\text { shared with } \\
\text { members on } \\
\text { request } \\
\text { Organizations } \\
\text { sign up to the } \\
\text { initiative } \\
\text { because of } \\
\text { pressure from } \\
\text { existing } \\
\text { members that } \\
\text { are part of } \\
\text { supply chain } \\
\text { Good practice } \\
\text { case studies } \\
\text { publicly } \\
\text { available }\end{array}$ \\
\hline
\end{tabular}

Table 3 - Voluntary social sustainability assessment initiatives as sources of institutional pressure 


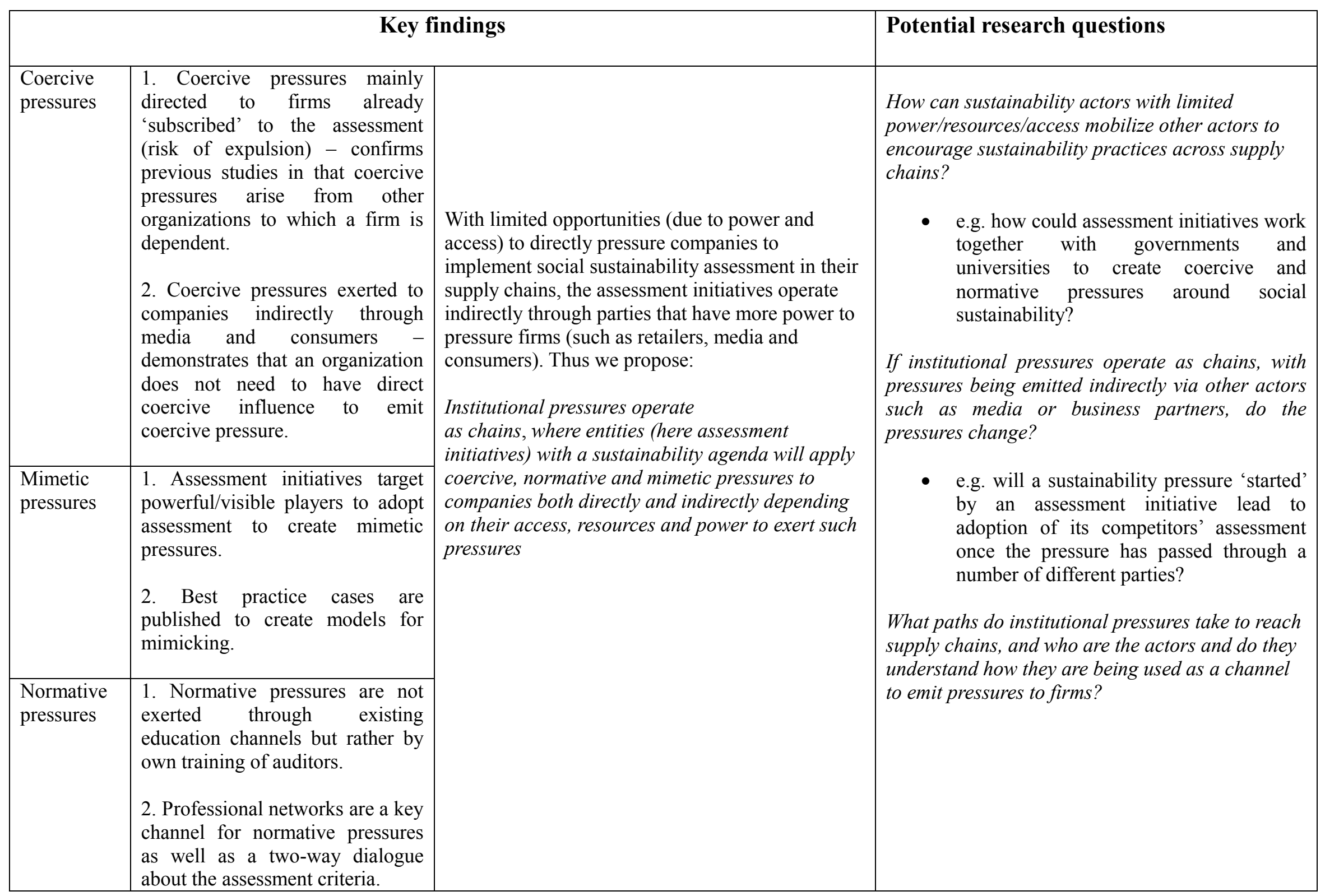

Table 4 - Key findings and potential research questions 